\title{
Experimental and full-scale pilot plant constructed wetlands for municipal wastewaters treatment
}

\author{
Gemma Ansola $^{\mathrm{a}, *}$, Juan Manuel González ${ }^{\mathrm{b}}$, Rubén Cortijo ${ }^{\mathrm{b}}$, Estanislao de Luis ${ }^{\mathrm{a}}$ \\ a Area of Ecology, Environmental Biotechnology Research, University of León, León 24071, Spain \\ ${ }^{\mathrm{b}}$ Environmental Institute, University of León, León 24071, Spain
}

Received 9 October 2002; received in revised form 3 July 2003; accepted 1 August 2003

\begin{abstract}
The Hierarchical Mosaic of Aquatic Ecosystems $\left(\mathrm{HMAE}^{\circledR}\right.$ ) was originally developed in Belgium by applying the ecological adaptations of hydrophyte plants to flooded and polluted conditions. The system consisted of a stabilization pond (stage I) followed by a semi-aquatic ecosystem planted with helophytes (stage II) and by a terrestrial ecosystem (stage III) where ligneous species are planted. An $\mathrm{HMAE}^{\circledR}$ experimental system net treatment area of $9.4 \mathrm{~m}^{2}$ per one equivalent inhabitant (e.i.) showed a high average performance for SS $(66.5 \%)$; $\mathrm{COD}(89 \%)$; $\mathrm{BOD}_{5}(87.5 \%)$ and fecal bacteria $(99.997 \%)$. The decrease of the treatment area of $2.8 \mathrm{~m}^{2} /$ e.i. showed a average high performance for SS $(75 \%)$; $\mathrm{COD}(80 \%)$; $\mathrm{BOD}_{5}(82 \%)$ and fecal bacteria (99.9\%). An $\mathrm{HMAE}^{\circledR}$ system was built in Bustillo de Cea (Leon, northwest of Spain) and their removal efficiency was studied. Organic matter, nutrients and fecal bacteria were fortnightly analyzed. The whole system showed removal efficiencies in start-up as high as $98 \%$ for solids, $95 \%$ for $\mathrm{BOD}_{5}$ and up to $99.99 \%$ for fecal bacteria.
\end{abstract}

(C) 2003 Elsevier B.V. All rights reserved.

Keywords: Constructed wetlands; Iris; Nutrients; Organic matter; Pathogens; Salix; Typha; Wastewater

\section{Introduction}

The European Union Directive 91/271/EEC (ECOD, 1991) establishes a series of requirements for wastewater treatment plants effluents and removal efficiency that must be applied before the end of December 2005 for populations between 2000 and 15,000 equivalent inhabitants and an adequate treatment for populations lower than 2000. In León province (Spain) localities with fewer than 10,000

\footnotetext{
* Corresponding author. Tel.: +34-987-291-568; fax: +34-987-291-501.

E-mail address: deggag@unileon.es (G. Ansola).
}

inhabitants are about $97 \%$, and those with fewer than 2000 inhabitants represent $82.5 \%$ of the total province population. Most of these small towns need an integral wastewater treatment. For small urban areas and rural villages to conform with European Union norms concerning outflow quality from wastewater treatment plants, adequate technology with low investment and operation costs but with a high performance level must be found, especially as regards nitrogen and phosphorus removal. With the techniques available, nutrient outflow concentrations are far from the compulsory quality standards of the European Union for sensitive areas $(10-15 \mathrm{mg} \mathrm{N} / \mathrm{l}$ and $1-2 \mathrm{mg} P / 1)$. 
It has been widely demonstrated in Spain that conventional (activated sludge) treatment systems applied to small rural municipalities have many operational and management problems, being at present inactive or abandoned for the most part. As an alternative to the conventional treatment systems, low-cost and natural systems are increasingly applied in Spain, where stabilization ponds are one of the most adequate and applied. Constructed wetlands have not been, at this time, considered as a treatment option by the administration, mainly due to the absence of previous experiences on pilot plants in Spain.

The use of constructed wetlands to treat non-point pollution and wastewater has been investigated in numerous general studies (Hammer, 1989; Cooper and Findlater, 1990; Olson and Marshall, 1992; Moshiri, 1993; Kadlec and Knight, 1996; and references therein). More concrete problems have been researched recently (e.g. Pant et al., 2001; Gómez Cerezo et al., 2001); Braskerud, 2002a,b; Söderqvist, 2002; Pant and Reddy, 2003). Most of the key processes involved in the macrophyte-based wastewater treatment are well documented: organic matter retention (e.g. Nguyen, 2000), nutrients removal (e.g. Mitsch et al., 2000; and references therein) and pathogen reduction (e.g. Perkins and Hunter, 2000). Different technologies have been successfully used; each one is unique (Reddy and DeBusk, 1985; Mara et al., 1992, 1998, Kadlec, 1995; Cadelli et al., 1998; Younger et al., 1998).

The Hierarchical Mosaic of Aquatic Ecosystems $\left(\mathrm{HMAE}^{\circledR}\right)$ has been developed and it has enabled us to compare the overall wastewater treatment efficiency of using different aquatic, semi-aquatic, and terrestrial ecosystems in the same climatic conditions and organic influent loads (Radoux, 1988, 1989 and Cadelli et al., 1998). The $\mathrm{HMAE}^{\circledR}$ system was originally developed in Belgium (Radoux and Kemp, 1982) by applying the ecological adaptations of hydrophyte plants to flooded and polluted conditions. The system consisted of a stabilization pond (stage I) followed by a semi-aquatic ecosystem planted with helophytes (stage II) and by a terrestrial ecosystem (stage III) where ligneous species are planted.

The objective of this work was to study the applicability of this system to the wastewater and climatic conditions of the region and to know the parameters for the design of a full-scale process and to compare the two different systems: experimental design (Ansola et al., 1995a,b) and pilot design on a full scale.

\section{Materials and methods}

\subsection{Experimental design}

The MHEA $^{\circledR}$ methodological and technological process developed by the Viville Experimental Plant (FUL, Belgium, Radoux and Kemp, 1982) was used to design the Experimental Plant in Mansilla de las Mulas, a village of 1637 inhabitants located in a rural area in the northwest of the Iberian Peninsula. The climatic type of the area is Mediterranean (Papadakis, 1961) with $498.6 \mathrm{~mm}$ annual rainfall approximately and $11{ }^{\circ} \mathrm{C}$ mean annual temperature.

A free water ecosystem (water stabilization pond, WSP, volume $=11 \mathrm{~m}^{3}$ and hydraulic residence time $=1.1$ days) is used as a first-stage treatment and supplies two series with different flow. Each series is formed by three glass fiber tanks (each with a total volume of $0.6 \mathrm{~m}^{3}$, a surface of $1.1 \mathrm{~m}^{2}$ and a depth of $0.55 \mathrm{~m}$ ). The first tanks are filled up to a $25 \mathrm{~cm}$ height with $6-8 \mathrm{~mm}$ diameter gravel and the water flows over the substrate (semi-aquatic ecosystem with surface regime, free water system (FWS)) and rise to a height of $20 \mathrm{~cm}$. The effective water volume is reduced to $0.29 \mathrm{~m}^{3}$ (Ansola et al., 1995). These tanks were planted with $30 \mathrm{U} / \mathrm{m}^{2}$ of Typha latifolia collected from their natural environment.

The two following stages on series (terrestrial ecosystems) are completely filled with gravel and planted with $15 \mathrm{U} / \mathrm{m}^{2}$ of 1 -year-old specimens of willow (Salix atrocinerea). These tanks worked as subsurface flow (SSF) systems (Fig. 1). The plants were planted in spring 1997 and plants grew dense and robust.

The system is continuously fed with domestic raw wastewater at an hydraulic load of 1.6 and $5.3 \mathrm{~cm}$ per day (70 and 2351 per day) for series 1 and 2, respectively, in order to simulate the behaviour of the pilot full scale plant of Bustillo de Cea. If the hydraulic load of 1 e.i. corresponds to 1501 per day, the net treatment area for series 1 and 2 will be 9.4 and $2.8 \mathrm{~m}^{2} /$ e.i. The retention time corresponds to 1.6 days for series 1 and 0.5 days for series 2 . The influent average water $\mathrm{pH}$ was 7.52 ; temperature was $19.23^{\circ} \mathrm{C}$; 


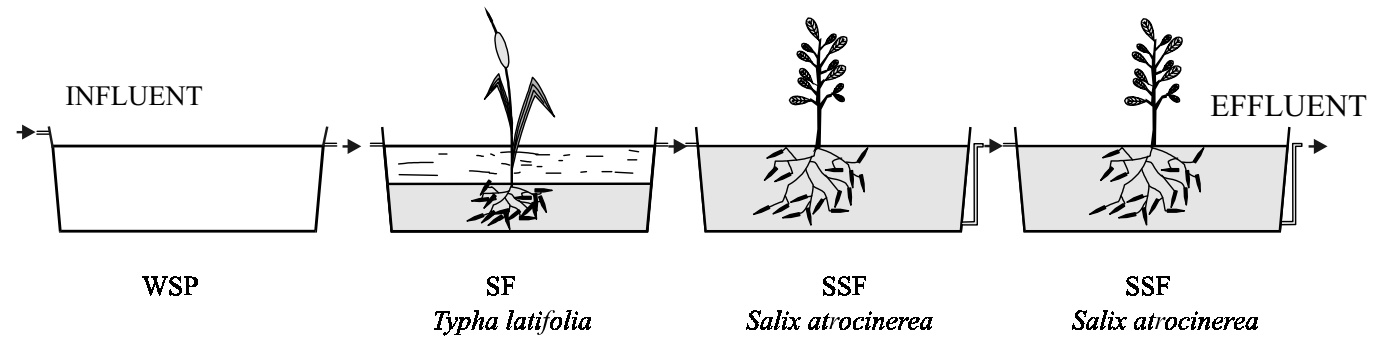

Fig. 1. The testing procedure of the experimental design plant of Mansilla de las Mulas used in series 1 and 2.

conductivity was $360 \mu \mathrm{S} / \mathrm{cm}$; and dissolved oxygen $1.88 \mathrm{mg} / \mathrm{l}$. Dissolved oxygen in effluent of series 1 was $3.87 \mathrm{mg} / \mathrm{l}$. No other important differences were observed.

The operational experimental flow was calculated so that we could test the minimum and maximum flow to design the pilot plant on a full scale.

\subsection{Pilot design on a full scale}

The location of Bustillo de Cea, in the northeast province of León (Spain), has 250 inhabitants in the winter, increasing to 400 in full summer. This location has been chosen as an experimental prototype in order to draw conclusions for operations and maintenance costs to obtain an effluent according to the European Union Directive 91/271/CEE by the year 2005 (ECOD, 1991).

The climatic type of the area is Mediterranean (Papadakis, 1961) with $546.7 \mathrm{~mm}$ annual rainfall approximately and $10.2^{\circ} \mathrm{C}$ mean annual temperature.

We have suggested setting up a $890 \mathrm{~m}^{2}$ full scale pilot plant for integral municipal wastewater treatment. This system is made up of four tanks of artificial aquatic ecosystems following the Lallaing example (Radoux et al., 1995, 1997). The mean wastewater flow is $9.5 \mathrm{~m}^{3}$ per day in winter and twice this volume in summer. The maximum flow is over $7.7 \mathrm{~m}^{3} / \mathrm{h}$. The wastewater treatment plant has been sized for a maximum flow of $0.61 / \mathrm{s}$ (Fig. 2). The rated retention time correspond to 10.5 days. The influent average water $\mathrm{pH}$ was 7.69 ; temperature was $14.43^{\circ} \mathrm{C}$; conductivity was $824.5 \mathrm{~S} / \mathrm{cm}$; and dissolved oxygen $2.18 \mathrm{mg} / \mathrm{l}$.

The distribution of surface has been as follows: $230 \mathrm{~m}^{2}$ for the first basin formed by a lagoon (WSP, aquatic ecosystem) of up to $2 \mathrm{~m}$ in depth where the inflow enters and $1.5 \mathrm{~m}$ where the out-flow goes out, reconstructing an aquatic ecosystem with algae (basin 1 in Fig. 2); $210 \mathrm{~m}^{2}$ for the second basin where 15 plants $\mathrm{m}^{-2}$ of T. latifolia taken from their natural habitat have been planted. In this basin the water circulation is by free flow (FWS, basin 2 in Fig. 2); $87.5 \mathrm{~m}^{2}$ for basin 3 , which also has surface flow (FWS) and where 15 plants $\mathrm{m}^{-2}$ of Iris pseudacorus were planted (basins 2 and 3 are semi-aquatic ecosystems), and $362.5 \mathrm{~m}^{2}$ for basin 4, which acts as a gravel filter without vegetation with sub-surface flow (SSF, terrestrial ecosystem).

\subsection{Analytical procedures}

The analyses conducted on both systems were based on physico-chemical and microbiological parameters according to the APHA-AWWA-WPCF (1989) recommendations: Total suspended solids (TSS), method 2540 D. Total volatile solids (TVS); method $2540 \mathrm{E}$. Chemical oxygen demand (COD), method 5220 A. Biological oxygen demand 5 days $\left(\mathrm{BOD}_{5}\right)$, method 5210 B. Ammonium $\left(\mathrm{NH}_{4}{ }^{+}\right)$, method $4500-\mathrm{NH}_{3} \mathrm{~F}$. Total Kjeldahl nitrogen (TKN), method $4500-\mathrm{N}_{\text {org }}$ B. Total phosphorus (TP), methods 4500-P B and E. Faecal coliforms (FC), method 9222 D. And fecal streptococcus (FS), method $9230 \mathrm{C}$.

These parameters were conducted on the influent water and on the treated wastewater along a year (sampling each 15 days: experimental design August 1997 to July 1998 and pilot design on a full scale October 1999 to September 2000).

The European Council Directive (ECOD, 1991) was taken as the reference for the values. It should be noted that there is no legislation on residual matter that takes into account the microbiological parameters or 


\section{Bustillo de Cea}

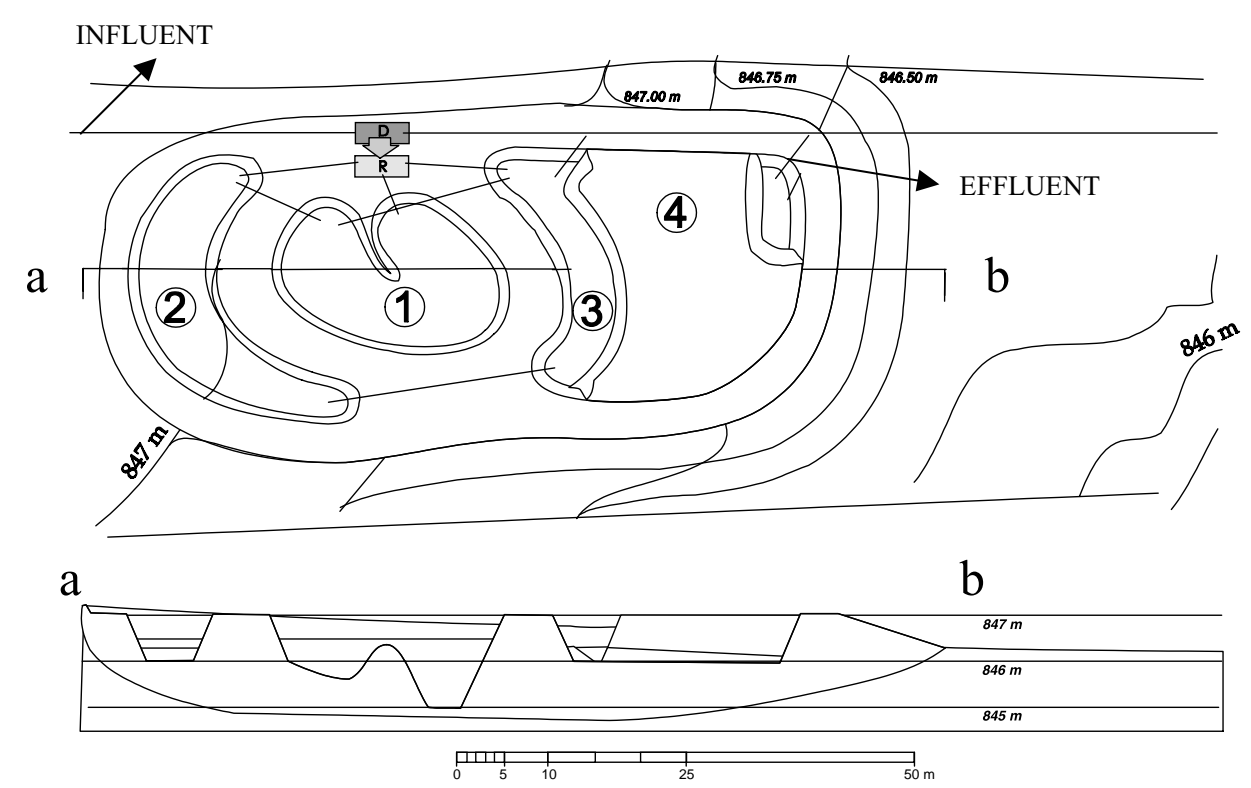

Fig. 2. The pilot full-scale treatment plant scheme. D and R pretreatment; (1) WSP basin, (2) FWS with Typha, (3) FWS with Iris; and (4) SSF with gravel.

the degree of performance required by the developed treatment.

A Student's $t$-distribution test was used (because the values showed a normal distribution but no homocedastics) to see if there were significant differences in the removal of the different polluting agents between the two experimental series of vegetation and the different phases of full-scale treatment.

\section{Results and discussion}

\subsection{Experimental system}

During the study period in its experimental phase, satisfactory results have been obtained on both test series, while the results of the series, using a lower flow, were excellent.

\subsubsection{Organic matter removal}

The organic matter undergoes high removal although the values of these parameters in the raw wastewater are not very high owing to its raised, natural and uncontrolled dilution.
Both series have exceeded the average reduction of $79 \%$ of $\mathrm{COD}$ and $\mathrm{BOD}_{5}$ although the removal of TSS reaches $65 \%$ as can be seen in Table 1 .

It should be noted that the organic matter is reduced by $99 \%$ in the samples tested in the spring of the vegetative period, probably owing to better conditions in the system after a period of adaptation of the vegetation to its new habitat.

In Table 1 it can be seen that no significant differences exist in the removal of the organic matter.

The average removal percentages obtained are slightly lower than those achieved by Radoux (1988) and Radoux et al. (2000) (TSS $=97.3 \%$, COD $=$ $93.6 \%$ and $\mathrm{BOD}_{5}=97.8 \%$ ) in the sewage plants with an experimental design.

\subsubsection{Nutrients removal}

In the series 1 using 701 per day, the highest value of the effluent of the total Kjeldahl nitrogen was $0.82 \mathrm{mg}$ $\mathrm{N} / \mathrm{l}$ and the lowest was 0.26 as opposed to the $12.86 \mathrm{mg}$ $\mathrm{N} / \mathrm{l}$ average concentration on entering; with an average removal of $95.89 \%$. The removal of nutrients in the series using a load three times higher than the previous one (series 2 ) was again satisfactory, reaching 
Table 1

Influent and effluents average values (series 1 and 2)

\begin{tabular}{|c|c|c|c|c|c|c|c|c|}
\hline & \multirow[t]{2}{*}{ Influent } & \multicolumn{3}{|c|}{ Series 1 (701 per day, $9.4 \mathrm{~m}^{2} / \mathrm{e}$.i. $)$} & \multicolumn{3}{|c|}{ Series 2 (2351 per day, $2.8 \mathrm{~m}^{2} /$ e.i. $)$} & \multirow[t]{2}{*}{ Student's $t$} \\
\hline & & Effluent & Average $(\%)$ & S.D. & Effluent & Average $(\%)$ & S.D. & \\
\hline TSS (mg/l) & 32.31 & 11.05 & 66.51 & 28.8 & 9 & 74.26 & 25.6 & \\
\hline $\mathrm{BOD}_{5}(\mathrm{mg} \mathrm{O} / \mathrm{l})$ & 33.18 & 5 & 87.48 & 14.0 & 7.5 & 81.71 & 19.5 & \\
\hline $\mathrm{COD}\left(\mathrm{mg} \mathrm{O}_{2} / \mathrm{l}\right)$ & 65.96 & 11.79 & 89.09 & 5.3 & 21.76 & 79.38 & 16.1 & \\
\hline $\mathrm{NH}_{4}{ }^{+}(\mathrm{mg} \mathrm{N} / \mathrm{l})$ & 6.73 & 0.15 & 98.11 & 0.6 & 3.2 & 59.22 & 22.4 & $* *$ \\
\hline TKN (mg N/l) & 12.86 & 0.57 & 95.89 & 2.2 & 3.67 & 74.40 & 19.7 & $*$ \\
\hline TP (mg P/l) & 2.07 & 0.17 & 92.55 & 5.2 & 0.82 & 68.14 & 16.6 & $* *$ \\
\hline $\mathrm{FC}(\mathrm{col} / 100 \mathrm{ml})$ & 14034 & 5 & 99.997 & 0.1 & 52 & 99.91 & 0.2 & \\
\hline
\end{tabular}

Average performance of percent reductions obtained in the treatment of the two experimental pilot series. Significant differences obtained between the experimental text series 1 and 2. (August 1997 to July 1998); equivalent inhabitant (e.i.).

* $P<0.05$.

** $P<0.01$

an average $74.4 \%$ removal of total Kjeldahl nitrogen with effluent values of between 0.68 and $5.12 \mathrm{mg} \mathrm{N} / \mathrm{l}$ (Table 1).

The series 1 reduced $\mathrm{NH}_{4}{ }^{+}$by an average of $98.11 \%$ with an effluent average value of $0.15 \mathrm{mg}$ N/l. The average removal of $\mathrm{NH}_{4}{ }^{+}$in the series 2 is $59.22 \%$ with an average value in the effluent of $3.2 \mathrm{mg} \mathrm{N} / \mathrm{l}$ (Table 1).

At the same time, we have obtained a reduction of $68.14 \%$ in the total phosphorus, managing to reduce values in the final series 2 effluent to $0.82 \mathrm{mg} P / 1$. The series 1 test reduced TP by an average of $92.55 \%$, obtaining values lower than $0.2 \mathrm{mg} / \mathrm{l}$ in the effluent (Table 1).

Significant differences have been observed between the two experimental series in the rate of removal of different nutrients.

The values of the " $t$ " statistics for ammonium and total phosphorus are notable with a significance of $99 \%$ and for TKN with a significance of $95 \%$. In all cases, the series with the longest hydraulic retention time removes considerably more of nutrients.

\subsubsection{Pathogen removal}

The removal of fecal coliforms reaches the value of $100 \%$ in numerous samples, however the average value is $99.997 \%$ (average effluent value $=$ $5 \mathrm{col} / 100 \mathrm{ml}$ ) in series 1 and $99.91 \%$ (average effluent value $=52 \mathrm{col} / 100 \mathrm{ml}$ ) for series 2 owing to the fact that the samples include the winter period in which the removal of this parameter is affected (Table 1).

Although the reduction of pathogenic organisms is higher in the experiment with a flow of 701 per day (series 1), significant differences have not been observed in relation to the series using 2351 per day for influent flow (series 2).

\subsubsection{Relationship between mass load and effluent values}

Figs. 3-5 show the relationship that exists between the load and the effluent values of the analyzed parameters. For the seven studied variables it has been observed that there is a positive linear relationship between increasing load and performance of removal, thus allowing the peak pollution to be adsorbed during the period of experimentation.

In Fig. 3, it is possible to observe that a high correlation between the organic load dispensed to the system and effluent values does not exist during the experiment. Also, it can be seen that the effluent $\mathrm{BOD}_{5}$ value becomes stabilized over $3 \mathrm{~g} / \mathrm{m}^{2}$ per day in samples that are not greater than $11 \mathrm{mg} \mathrm{O} / 1$. For these reason, the point of saturation has not been determined over $8 \mathrm{~g} / \mathrm{m}^{2}$ per day.

In the case of the relationship between the COD inlet load, and the effluent values for this parameter in the (Fig. 3b), it is observed that inlet values over $4.5 \mathrm{~g} / \mathrm{m}^{2}$ per day cause a COD effluent values around $30-50 \mathrm{mg} \mathrm{O}_{2} / 1$.

The value, obtained in the effluent of both parameters, $\mathrm{BOD}_{5}$ and $\mathrm{COD}$, are in agreement with stands of European Directive.

At Fig. 4 it can be observed, that the correlations obtained between the inlet loads of TKN, ammonium, and TP and the effluent values of these parameters are also not high. 

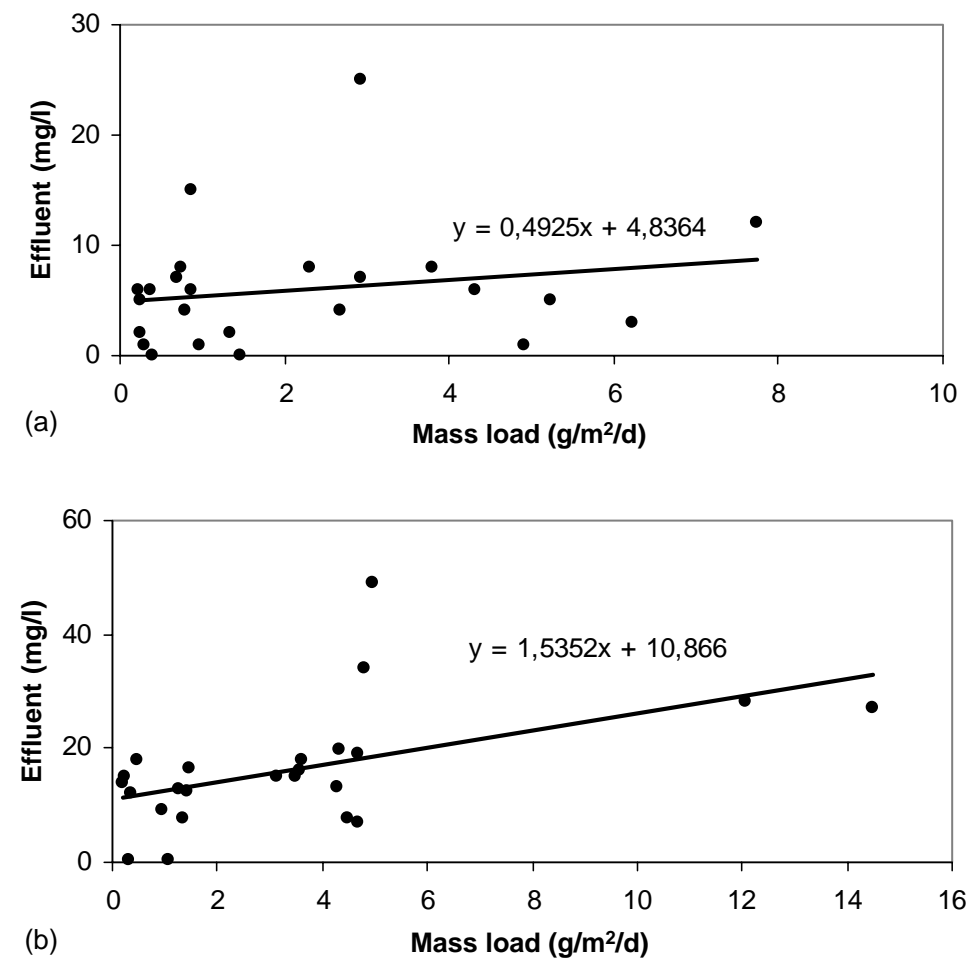

Fig. 3. Relationship between effluent values and loading rates for (a) $\mathrm{BOD}_{5}$ and (b) COD of experimental design.

According to Fig. 4a, a load higher than $1 \mathrm{~g} / \mathrm{m}^{2}$ per day of TKN maintains the effluent values of TKN below the established by the European Union. In the case of ammonium, an effluent value that does not exceed $10 \mathrm{mg} \mathrm{N} / \mathrm{l}$ also is determined by an inlet load around $1 \mathrm{~g} / \mathrm{m}^{2}$ per day. Tanner et al. (2002), working with Schoenoplectus, obtain a very high correlation $\left(R^{2}=\right.$ $0.96)$ between the applied load and the concentration of TN, much more elevated than the obtained one in our experiment.

In the case of the TP, Fig. 4c illustrates a small increase of effluent TP when increasing inlet load, finding the superior limit in $0.2 \mathrm{~g} / \mathrm{m}^{2}$ per day over which the value of the effluent would exceed to the value established like limit by the EU for sensitive zones. In Fig. 5, it is possible to be observed how a load up to $2,750,000 \mathrm{col} / \mathrm{m}^{2}$ per day into the experimental system can cause a reduction in the effluent value of fecal coliforms to below the $200 \mathrm{col} / 100 \mathrm{ml}$, with the absence of high correlation between both variables.

\subsection{Pilot plant on a full scale}

Table 2 shows the average characteristics of the wastewater in the location of Bustillo de Cea during the sampling period, as well as the average results ob-

Table 2

Average values of the influent and effluent as seen in the average performance of the full-scale system in Bustillo de Cea. (October 1999 to September 2000)

\begin{tabular}{|c|c|c|c|}
\hline & Influent & Effluent & $\begin{array}{l}\text { Average } \\
\text { removal }(\%)\end{array}$ \\
\hline TSS (mg/l) & 188.25 & 34.21 & 60.93 \\
\hline $\mathrm{BOD}_{5}\left(\mathrm{mg} \mathrm{O} \mathrm{O}_{2} / \mathrm{l}\right)$ & 154.80 & 21.70 & 61.44 \\
\hline $\mathrm{COD}\left(\mathrm{mg} \mathrm{O}_{2} / \mathrm{l}\right)$ & 294.79 & 81.38 & 59.47 \\
\hline $\mathrm{NH}_{4}+(\mathrm{mg} \mathrm{N} / \mathrm{l})$ & 27.80 & 24.15 & 33.04 \\
\hline TKN (mg N/l) & 36.85 & 28.31 & 35.59 \\
\hline $\mathrm{TP}(\mathrm{mg} \mathrm{P} / \mathrm{l})$ & 19.99 & 9.74 & 34.84 \\
\hline $\mathrm{FC}(\mathrm{col} / 100 \mathrm{ml})$ & $19 \times 10^{6}$ & 367044 & 96.45 \\
\hline FS $(\mathrm{col} / 100 \mathrm{ml})$ & 167978 & 5385 & 91.73 \\
\hline
\end{tabular}

The average removal was calculated as the average of removal in each sample. 


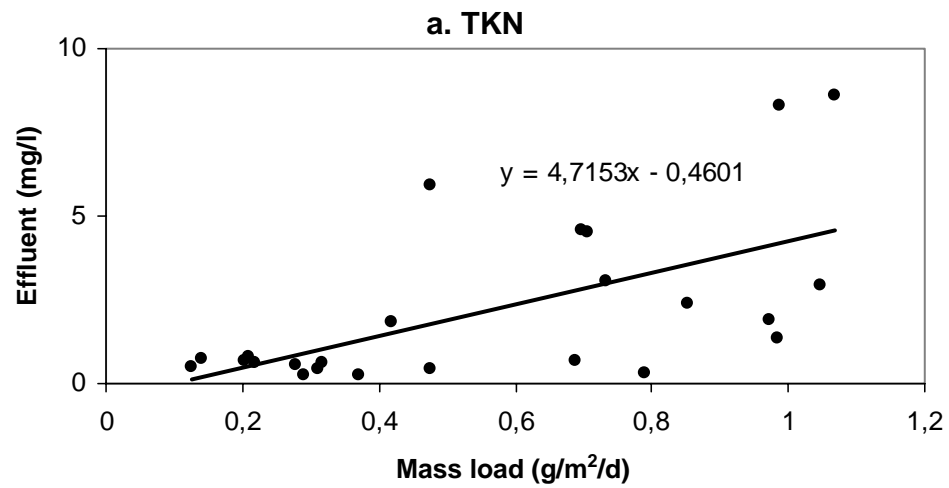

b. $\mathrm{NH}_{4}^{+}$

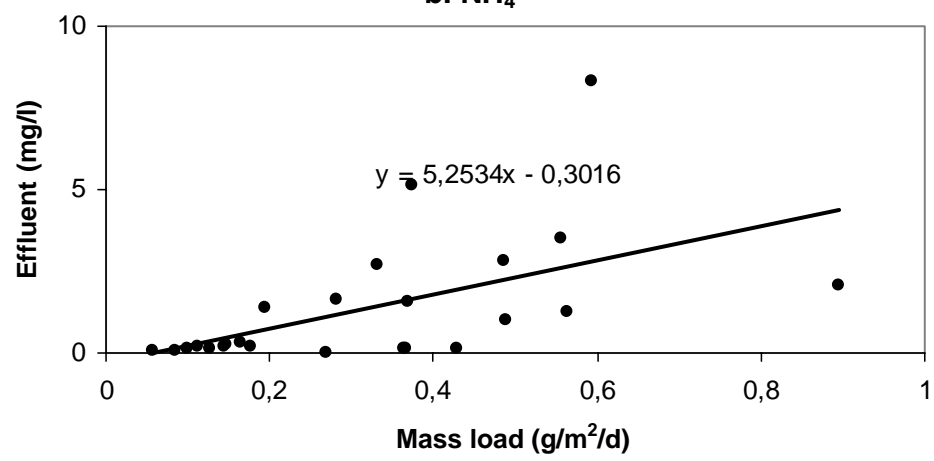

c. TP

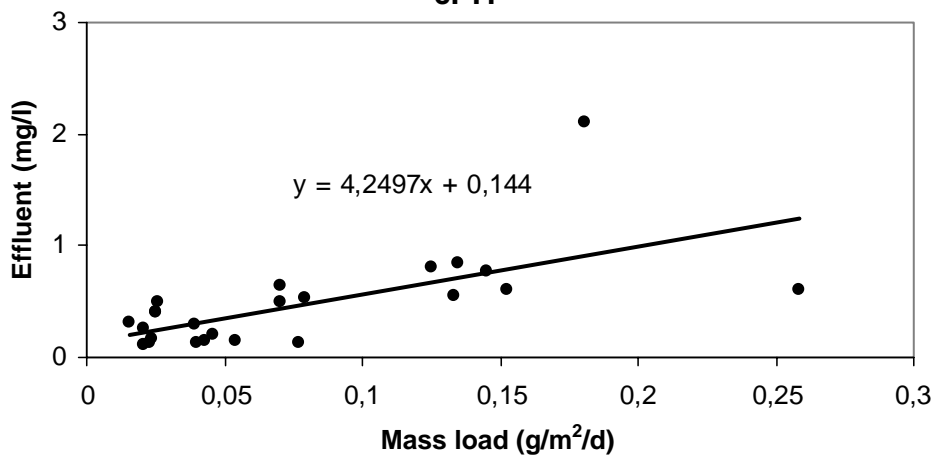

Fig. 4. Relationship between effluent values and loading rates for nutrients of experimental design.

tained during the first month of the operation time and the first vegetative period of the helophytes after being transplanted from their natural habitat.

As can be seen from Table 2, the average performances obtained during the whole study period have not been very high. However, there is an appreciable difference between the average values during the active growth of the wetland system (May-September) and the resting period (October-December) in which the performances fall considerably and cause the average value to go down as much as 10 times in some of the parameters, as occurs in the removal of nutrients (Table 3).

Seasonal differences in nitrate removal were shown by Spieles and Mitsch (2000) and in several parameters by Radoux et al. (1995). Also, these are seasonal differences in the elimination of $\mathrm{N}$ and $\mathrm{P}$ in the work made by Tanner (2001) with Schoenoplectus. 


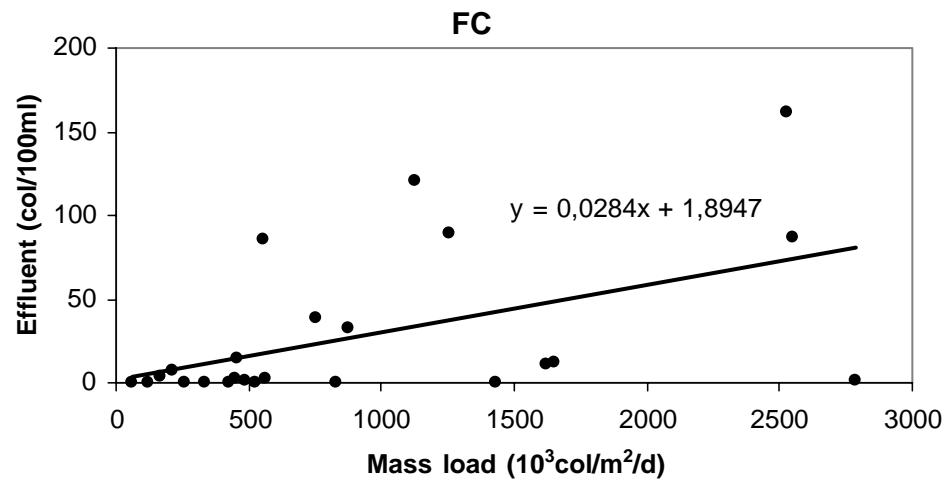

Fig. 5. Relationship between effluent values and loading rates for pathogens of experimental design.

Table 3

Average values of removal obtained during the different sample periods of the full-scale system in Bustillo de Cea

\begin{tabular}{lll}
\hline & $\begin{array}{l}\text { Average removal } \\
\text { (October-December) } \\
(\%)\end{array}$ & $\begin{array}{l}\text { Average removal } \\
\text { (May-September) } \\
(\%)\end{array}$ \\
\hline $\mathrm{TSS}(\mathrm{mg} / \mathrm{l})$ & 35.06 & 78.17 \\
$\mathrm{BOD}_{5}(\mathrm{mg} \mathrm{O} / \mathrm{l})$ & 39.13 & 76.32 \\
$\mathrm{COD}\left(\mathrm{mg} \mathrm{O}_{2} / \mathrm{l}\right)$ & 37.85 & 73.88 \\
$\mathrm{NH}_{4}{ }^{+}(\mathrm{mg} \mathrm{N} / \mathrm{l})$ & 4.47 & 52.08 \\
$\mathrm{TKN}(\mathrm{mg} \mathrm{N} / \mathrm{l})$ & 3.57 & 56.93 \\
$\mathrm{TP}(\mathrm{mg} \mathrm{P} / \mathrm{l})$ & 5.44 & 54.40 \\
$\mathrm{FC}(\mathrm{col} / 100 \mathrm{ml})$ & 99.08 & 95.14 \\
$\mathrm{FS}(\mathrm{col} / 100 \mathrm{ml})$ & 89.23 & 92.98 \\
\hline
\end{tabular}

The removal of organic matter is notable. In spring and summer it exceeds $70 \%$ in average removal values and it does not reach $40 \%$ in autumn. The removal of nutrients presents a similar case, with the removal of $\mathrm{TKN}$, during the period of highest temperatures, rising to more than $56 \%$ while the removal of TKN and TP do not exceed $5.5 \%$ during the analyses from October to December. The difference between both periods is not so obvious in the removal of the indicating bacteria of the fecal pollution (Table 3). This is probably due to the fact that the most intensive processes of removal are predation, competition, protolysis or filtration (García and Bécares, 1997). A global reduction can be seen in all the chemical parameters. An increase, in both parameters during the pond phase, is to be seen in fecal coliforms and fecal streptococcus. This may be due to poor pretreatment in the first phase of the analysis, hence considerably increasing the average value (Table 4).

Based on a more detailed analysis and concentrating on the average removal of four parameters, Table 5 illustrates that the stage represented by tanks 2 and 3 (FWS) and filled with T. latifolia and $I$. pseudacorus reaches higher partial average performances for organic matter (49\%), nutrients (30\%) and fecal pollution $(94 \%)$. A statistical analysis has been conducted to observe the existence of significant differences (Student's $t$ ) in the elimination of the chosen parameters between the different phases of the treatment. The results obtained are shown in Table 6.

Between the stabilizing pond (WSP) and the tanks 2 and 3 (FWS) there are significant differences (99\%) in the removal of phosphorus and pathogens. A higher value of removal is produced in the FWS vegetated

Table 4

Average parameter values obtained in the different phases of treatment of the full scale system

\begin{tabular}{llllll}
\hline & $\mathrm{BOD}_{5}\left(\mathrm{mg} \mathrm{O}_{2} / \mathrm{l}\right)$ & $\mathrm{NH}_{4}{ }^{+}(\mathrm{mg} \mathrm{N} / \mathrm{l})$ & $\mathrm{TP}(\mathrm{mg} \mathrm{P} / \mathrm{l})$ & $\mathrm{FC}(\mathrm{col} / 100 \mathrm{ml})$ & $\mathrm{FS}(\mathrm{col} / 100 \mathrm{ml})$ \\
\hline Influent & 155 & 28 & 20 & $1.5 \times 10^{6}$ & 167978 \\
WSP & 97 & 27 & 13 & $35.6 \times 10^{6}$ & 623911 \\
FWS & 41 & 19 & 10 & $3.5 \times 10^{6}$ & 563339 \\
SSF & 42 & 24 & 10 & 367044 & 5663 \\
\hline
\end{tabular}

WSP: water stabilization pond; FWS: free water system; SSF: subsurface flow. 
Table 5

Average removal percentages obtained in the different phases of treatment of the full scale system

\begin{tabular}{lllll}
\hline Treatment system & $\mathrm{BOD}_{5}$ & $\mathrm{NH}_{4}{ }^{+}$ & $\mathrm{TP}$ & $\mathrm{FC}$ \\
\hline $\begin{array}{l}\text { Water stabilization pond } \\
\quad \text { (WSP, basin 1) }\end{array}$ & 34.07 & 16.60 & 4.05 & 44.73 \\
$\begin{array}{l}\text { Free water system (FWS, } \\
\text { basins 2 and 3) }\end{array}$ & 48.52 & 28.96 & 31.90 & 93.90 \\
$\begin{array}{l}\text { Subsurface flow (SSF, basin 4) } \\
\text { und }\end{array}$ & 27.03 & 21.11 & 29.77 & 44.60 \\
\hline
\end{tabular}

Table 6

Significant differences (Student's $t$ ) in the different phases of the treatment of full scale system (Bustillo de Cea)

\begin{tabular}{lllll}
\hline & $\mathrm{BOD}_{5}$ & $\mathrm{NH}_{4}{ }^{+}$ & $\mathrm{TP}$ & $\mathrm{FC}$ \\
\hline WSP-FWS & - & - & $* *$ & $* *$ \\
FWS-SSF & - & - & - & $*$ \\
WSP-SSF & - & - & $*$ & - \\
\hline
\end{tabular}

* $P<0.05$.

** $P<0.01$.

areas. Between the planting of Typha and Iris and the last stage (SSF), there are significant differences $(95 \%)$ in the removal of fecal coliforms with a higher performance in the stage with vegetation (Table 6). There are also significant differences in the removal of phosphorus (95\%) between the pond (WSP) and the gravel filter (SSF), the latter obtaining higher performances of nearly $30 \%$. In the analyses conducted, no significant differences between the filters (FWS and SSF) are apparent in this parameter. It should be noted, however, that the vegetation was in a period of stabilization. This presupposes that in subsequent studies, the differences that are already apparent between both stages, will be more significant. It has to be pointed out, however, that the data collected up to the present time, are from the first months of the operation time which presupposes that they will improve when the Salix are planted in the gravel bed.

\section{Conclusions}

\subsection{Experimental system}

There are no significant differences in the removal of organic matter and fecal pollution between the series using 9.4 and $2.8 \mathrm{~m}^{2} /$ e.i. Very significant differences between both series have been measured $(P<$
$0.01)$ in the removal of ammonium and TP. There are significant differences $(P<0.05)$ in both series in the removal of TKN.

The relationships obtained between the load applied to the system and the effluent values for the different analyzed parameters have been very low, not showing a strong correlation between both parameters.

\subsection{Full scale pilot plant}

The average performance of integral treatment of the full scale $\mathrm{HMAE}^{\circledR}$ system exceeds a $60 \%$ reduction in organic matter, a $30 \%$ reduction in nutrients, and a $90 \%$ removal of fecal pollution (Table 2).

The analyses conducted during the different seasons show large differences in the reduction of organic and nutrient pollution during the active growth period compared to the winter resting period.

In analyzing the system in its different phases, a better performance of removal in the system with FWS in relation to the WSP and the SSF has been observed. Highly significant differences $(P<0.01)$ have been observed between the systems WSP and FWS in the reduction of TP and FC and significant differences $(P<0.05)$ between WSP and SSF in the removal of $\mathrm{TP}$ and in the reduction of FC between FWS and SSF.

The results obtained point to the usefulness of the $\mathrm{HMAE}^{\circledR}$ as an integrated treatment of urban wastewater characteristic of small rural districts because the effluent conforms to the European Union Directive (ECOD, 1991).

\section{Acknowledgements}

This work was supported with grants from the Diputación Provincial of León (Spain) and the collaboration of Foundation Universitaire Luxembourgeoise, Belgium.

\section{References}

Ansola, G., Fernández, C., de Luis, E., 1995a. Removal of organic matter and nutrients from urban wastewater by using an experimental emergent aquatic macrophyte system. Ecol. Eng. 5, 13-19.

Ansola, G., Fernández, C., de Luis, E., 1995b. Removal of nutrients and organic matter from urban wastewater by using an experimental constructed wetland. In: Ramadori, R., Cingolani, 
L., Cameroni, L. (Eds.), Proceedings of the Natural and Constructed Wetlands for Wastewater Treatment and Reuse. Experiences, Goals and Limits. Perugia, pp. 39-46.

APHA-AWWA-WPCF, 1989. Clesceri, L.S., Greenberg, A.E., Trussell, R.R. (Eds.), Standard Methods for the Examination of Water and Wastewater, 17 ed. Baltimore, MD.

Braskerud, B.C., 2002a. Factors affecting nitrogen retention in small constructed wetlands treating agricultural non-point source pollution. Ecol. Eng. 18, 351-370.

Braskerud, B.C., 2002b. Factors affecting phosphorus retention in small constructed wetlands treating agricultural non-point source pollution. Ecol. Eng. 19, 41-61.

Cadelli, D., Radoux, M., Nemcova, M., 1998. Constructed wetlands in Belgium. In: Vymazal, J., Brix, H., Cooper, P.F., Green, M.B., Haberl, R. (Eds.), Constructed Wetlands for Wastewater Treatment in Europe. Backhuys Publishers, pp. 77-93.

Cooper, P.F., Findlater, B.C. (Eds.), 1990. Constructed Wetlands in Water Pollution Control. Pergamon Press, Oxford, UK, 605 pp.

ECOD No. L 135, 1991. Directiva del Consejo sobre el tratamiento de las aguas residuales urbanas. DOCE 91/271/CEE, pp. 40-52.

García, M., Bécares, E., 1997. Bacterial removal in three pilot scale wastewater treatment systems for rural areas. Water Sci. Technol. 35 (11-12), 197-200.

Gómez Cerezo, R., Suárez, M.L., Vidal-Abarca, M.R., 2001. The performance of a multi-stage system of constructed wetlands for urban wastewater treatment in a semiarid region of SE Spain. Ecol. Eng. 16, 501-517.

Hammer, D.A. (Ed.), 1989. Constructed Wetlands for Wastewater Treatment. Municipal, Industrial, and Agricultural. Lewis Publishers, Chelsea, MI, USA, 831 pp.

Kadlec, R.H., 1995. Overview: surface flow constructed wetlands. Water Sci. Technol. 32 (3), 1-12.

Kadlec, R.H., Knight, R.L., 1996. Treatment Wetlands. Lewis Publishers, Boca Raton, FL, 893 pp.

Mara, D.D., Mills, S.W., Pearson, H.W., Alabaster, G.P., 1992. Waste stabilization ponds: a viable alternative for small community treatment systems. J. CIWEM 6 (2), 72-78.

Mara, D.D., Cogman, C.A., Simkins, P., Schembri, C.A., 1998. Performance of the Burwarton estate waste stabilization ponds. J. CIWEM 12 (8), 260-264.

Mitsch, W.J., Horne, A., Nairn, R.W., 2000. Nitrogen and phosphorus retention in wetlands (special issue). Ecol. Eng. 14, 1-206.

Moshiri, G.A. (Ed.), 1993. Constructed Wetlands for Water Quality Improvement. Lewis Publishers, Boca Raton, FL, USA, 632 pp.

Nguyen, L.M., 2000. Organic matter composition, microbial biomass and microbial activity in gravel-bed constructed wetlands treating farm dairy wastewaters. Ecol. Eng. 16, 199221.

Olson, R.K., Marshall, K., 1992. The role of created and natural wetlands in controlling non point source pollution (special issue). Ecol. Eng. 1, 1-170.

Pant, H.K., Reddy, K.R., Lemon, E., 2001. Phosphorus retention capacity of root bed media of subsurface flow constructed wetlands. Ecol. Eng. 17, 345-355.
Pant, H.K., Reddy, K.H., 2003. Potential internal loading of phosphorus in a wetland constructed in agricultural land. Water Res. 37, 965-972.

Papadakis, P., 1961. Climatic Tables for the Word. Buenos Aires.

Perkins, J., Hunter, C., 2000. Removal of enteric bacteria in a surface flow constructed wetland in Yorkshire, England. Water Res. 34 (6), 1941-1947.

Radoux, M., Kemp, D., 1982. Aproche écologique et experimentale des potentialités épuratrices de quelques hélophytes: Phragmites australis (cav.) Trin. Ex Steud. Typha latifolia L. et Carex acuta L. Trib. Cebedeau 465-466 (35), 325-340.

Radoux, M., 1988. Epuration comparée des eaux usées domestiques par trois plantations hélophytiques et par lagunage à microphytes sous un même climat temperé. Ecol. Applic. 9 (1), 25-38.

Radoux, M., 1989. Epuration des eaux usées par hydrosère reconstituèe, Journèe D'Etude Cebedeau-IAWPRC, pp. 6268

Radoux, M., Cadelli, D., Nemcova, M., 1995. A mosaic of artificial ecosystems as a wastewater treatment plant: evaluation of the pilot plant of Lallaing (France). In: Ramadori, R., Cingolani, L., Cameroni, L. (Eds.), Proceedings of Natural and Constructed Wetlands for Wastewater Treatment and Reuse. Experiences, Goals and Limits. Perugia, pp. 275-284.

Radoux, M., Cadelli, D., Nemcova, M., 1997. A comparison of purification efficiencies of various constructed ecosystems (aquatic, semiaquatic and terrestrial) receiving urban wastewaters. In: Vymazal, J. (Ed.), Nutrient Cycling and Retention in Wetlands. Kluwer, Dordrecht. Wetlands Ecol. Manage. 4, 201-217.

Radoux, M., Cadelli, D., Nemcova, M., Ennabili, A., Ezzahri, J., Ater, M., 2000. Optimization of natural wastewater treatment technologies in the $\mathrm{MHEA}^{\circledR}$ experimental centre in M'Diq, Mediterranean coast of Morocco. In: Proceedings of the Seventh International Conference on Wetland Systems for Water Pollution Control. Lake Buena Vista, Florida, pp. $1145-1152$.

Reddy, K.R., DeBusk, W.F., 1985. Nutrient removal potential of selected aquatic macrophytes. J. Environ. Quality 14 (4), 459462.

Söderqvist, T., 2002. Constructed wetlands as nitrogen sinks in southern Sweden: an empirical analysis of cost determinants. Ecol. Eng. 19, 161-173.

Spieles, D.J., Mitsch, W.J., 2000. The effects of season and hydrologic and chemical loading on nitrate retention in constructed wetlands: a comparison of low- and high-nutrient riverine systems. Ecol. Eng. 14, 77-91.

Tanner, C.C., 2001. Growth and nutrient dynamics of softstem bulrush in constructed wetlands treating nutrient-rich wastewaters. Wetlands Ecol. Manage. 9, 49-73.

Tanner, C.C., Kadlec, R.H., Gibbs, M.M., Sukias, J.P.S., Nguyen, M.L., 2002. Nitrogen processing gradients in subsurfaceflow treatment wetlands-influence of wastewater characteristics. Ecol. Eng. 18, 499-520.

Younger, P.L., Large, A.R.G., Jarvis, A.P., 1998. Hydrology in a Changing Environment, vol. I, pp. 495-502. 